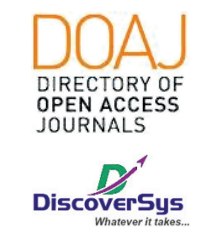

Published by DiscoverSys

\title{
Perbedaan olahraga aerobik intensitas sedang dan High-Intensity Interval Training (HIIT) terhadap kebugaran fisik pada mahasiswa Fakultas Kedokteran Universitas Udayana, Bali, Indonesia
}

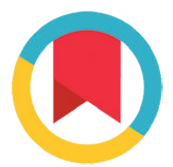

CrossMark

\author{
Komang Satrya Wirawan, ${ }^{1 *}$ I Putu Adiartha Griadhi ${ }^{2}$
}

\section{ABSTRACT}

Background: Exercise is a healthy habit, which is already a lot of becoming obsolete. In addition to able to increase our endurance, it can also indirectly reduce or even cure some disease. This study aims to know the difference in physical fitness between aerobic exercise with moderate intensity and High-Intensity Interval Training (HIIT).

Methods: A randomized observational experimental study using preand post-test group design was conducted among 16 respondents at Department of Physiology, Faculty of Medicine, Universitas Udayana, Bali, Indonesia during March-April 2016. The respondents were divided into 2 groups: Group 1 for High-Intensity Interval Training (HIIT) and Group 2 for moderate aerobic intensity exercise. Harvard Step Test was carried out to determine the physical fitness between both groups. Data were analyzed using SPSS version 23 for Windows.

Results: Most of the respondents were males (68.75\%) and age 21 years-old (68.75\%). Mann-Whitney test found no significant difference between HIIT and moderate training before and after the exercise ( $p=0.293 ; p=0.247$ ). However, a significant difference in physical fitness by Wilcoxon Test before and after exercise was found in HIIT $(p=0.001)$ and moderate exercise $(p=0.001)$ groups.

Conclusion: By doing aerobic exercise training, either high or moderateintensity, can lead to an increase in physical fitness. However, the difference obtained from both types of training is not too visible or insignificant.

Keywords: Aerobic, Harvard Step Test, Moderate Intensity Exercise, Physical Fitness, HIIT

Cite This Article: Wirawan, K.S., Griadhi, I.P.A. 2020. Perbedaan olahraga aerobik intensitas sedang dan High-Intensity Interval Training (HIIT) terhadap kebugaran fisik pada mahasiswa Fakultas Kedokteran Universitas Udayana, Bali, Indonesia. Intisari Sains Medis 11(1): $205-210$. DOl: 10.15562/ism.v11i1.535

\section{ABSTRAK}

Latar Belakang: Olahraga merupakan suatu kebiasaan sehat yang selama ini sudah banyak mulai ditinggalkan. Disamping mampu meningkatkan ketahanan tubuh kita, olahraga juga dapat secara tidak langsung mengurangi atau bahkan meyembuhkan beberapa penyakit.

'Mahasiswa Program Studi Pendidikan Dokter, Fakultas Kedokteran, Universitas Udayana, Bali, Indonesia

${ }^{2}$ Departemen IImu Faal, Fakultas Kedokteran, Universitas Udayana, Bali, Indonesia

*Korespondensi:

Komang Satrya Wirawan; Mahasiswa Program Studi Pendidikan Dokter, Fakultas Kedokteran, Universitas Udayana, Bali, Indonesia; wirawansatrya@gmail.com

Diterima: 18-06-2019 Disetujui:19-03-2020 Diterbitkan: 26-03-2020
Harvard Step Test dilakukan untuk menentukan kebugaran fisik antara kedua kelompok. Data dianalisis menggunakan SPSS versi 23 untuk Windows.

Hasil: Sebagian besar responden adalah laki-laki $(68,75 \%)$ dan berusia 21 tahun (68,75\%). Uji Mann-Whitney tidak menemukan perbedaan yang bermakna antara HIIT dan pelatihan sedang sebelum dan sesudah latihan ( $p=0,293 ; p=0,247)$. Namun, perbedaan yang bermakna dalam kebugaran fisik oleh Tes Wilcoxon sebelum dan sesudah latihan ditemukan pada kelompok HIIT $(p=0,001)$ dan olahraga sedang $(p=0,001)$.

Kesimpulan: Dengan melakukan latihan aerobik, baik intensitas tinggi atau sedang, dapat menyebabkan peningkatan kebugaran fisik. Namun, perbedaan yang didapat dari kedua jenis pelatihan ini tidak terlalu terlihat atau tidak signifikan. 


\section{PENDAHULUAN}

Olahraga merupakan suatu kebiasaan sehat yang selama ini sudah banyak mulai ditinggalkan. Dibalik mampu meningkatkan ketahanan tubuh kita tetapi dapat juga secara tidak langsung mengurangi atau bahkan meyembuhkan berbagai macam penyakit. ${ }^{1}$ Olahraga yang termasuk dalam kategori olahraga aerobik yaitu olahraga yang dilakukan secara terus-menerus dimana kebutuhan oksigen masih dapat dipenuhi tubuh. ${ }^{2}$ Sebagai contoh olahraga aerobik adalah gerak jalan cepat, jogging, lari, senam, renang, dan bersepeda. Olahraga aerobik merupakan latihan intensif yang menggerakkan dua tangan dan kedua kaki seperti jogging, bulu tangkis, berenang gaya krol (bukan gaya katak), bersepeda aktif (bukan sepeda statis). ${ }^{2}$ Ada pula yang disebut olahraga anaerobik yaitu olahraga dimana kebutuhan oksigen tidak dapat dipenuhi seluruhnya oleh tubuh. ${ }^{3}$ Sebagai contoh angkat besi, lari sprint 100 meter, tenis lapangan, dan bulu tangkis. Olahraga anerobik merupakan latihan olahraga yang dipakai oleh para atlet olahragawan untuk meningkatkan masa otot dan non-endurance sifatnya, seperti angkat beban dalam meningkatkan masa otot. ${ }^{3}$

Jogging atau lari santai adalah salah satu macam dari olahraga aerobik yang sangat mudah dilakukan, murah, dan ternyata mempunyai pengaruh terhadap kesehatan yang signifikan. ${ }^{4}$ Selain itu jogging juga dapat menjadi salah satu cara untuk menurunkan berat badan secara efektif karena jika dilakukan dengan waktu yang cukup jaringan lemak akan mudah hancur dan diubah menjadi energi. ${ }^{4}$

Hampir semua dari jenis-jenis olahraga aerobik mempunyai efek terhadap kesehatan tubuh kita salah satunya adalah terhadap peningkatan kebugaran fisik kita. Mengingat dimana masyarakat jaman sekarang yang sudah mulai banyak mengurangi kegiatan fisik diluar rumah dan lebih banyak menghabiskan waktu didalam rumah dengan tidak melakukan apapun atau sedentary lifestyle yang dapat memicu timbulnya berbagi macam penyakit salah satunya yang paling umum adalah obesitas. ${ }^{5}$

Oleh karena itu pentingnya untuk melakukan olahrga aerobik baik yang dengan intensitas sedang atau dengan melalukan HIIT atau High Intensity Interval Training. Latihan olahraga aerobik merupakan aktivitas yang bergantung terhadap ketersediaan oksigen untuk membantu proses pembakaran sumber energi, sehingga bergantung pula terhadap kerja optimal dari organ-organ tubuh, seperti: jantung, paru-paru, dan pembuluh darah untuk mengangkut oksigen agar proses pembakaran sumber energi dapat berjalan dengan sempurna. ${ }^{2}$
Metabolisme energi pada latihan olahraga aerobik berjalan melalui pembakaran simpanan lemak, karbohidrat, dan sebagian kecil (kurang dari lima persen) dari pemecahan simpanan protein yang terdapat didalam tubuh untuk menghasilkan adenosine trifosfat. Proses metabolism ketiga sumber energi ini berjalan dengan kehadiran oksigen yang diperoleh melalui proses pernapasan. ${ }^{6}$

Berdasarkan kajian teori diatas belum diketahui pasti olahraga aerobik jenis mana yang lebih mempunyai efek terhadap tubuh oleh karena itu penelitian ini dibuat untuk mengetahui perbedaan diantara melakukan olahraga aerobik dan High Interval Intensity Training (HIIT). ${ }^{7}$ Oleh karena itu penelitian bertujuan untuk mengetahui apakah terdapat perbedaan olahraga aerobik intensitas sedang dan High-Intensity Interval Training (HIIT) terhadap kebugaran fisik pada mahasiswa Fakultas Kedokteran Universitas Udayana, Bali, Indonesia.

\section{METODE}

Penelitian ini merupakan Eksperimental terhadap 16 responden dengan menggunakan Observational Randomized Pre and Post Test Group Design yaitu membandingkan antara perlakuaan terhadap dua kelompok. Kelompok pertama yaitu pemberian pelatihan HIIT pada mahasiswa. Kelompok kedua yaitu pemberian latihan aerobik dengan intensitas sedang pada mahasiswa. Penelitian dilakukan di 2 tempat yaitu di bagian Faal Fakultas Kedokteran Universitas Udayana yang berlokasi di Denpasar dan di lapangan Renon selama 2 minggu terhitung dari bulan Maret - April 2016 dengan intensitas latihan 3 kali dalam seminggu selama 2 minggu. Adapun kriteria inklusi dalam penelitian ini mencakup mahasiswa program studi S-1 Fakultas Kedokteran Universitas Udayana dan bersedia menjadi subjek penelitian dari awal hingga akhir penelitian.

Definisi dari HIIT atau olahraga aerobik dengan intensitas tinggi adalah olahraga aerobik dengan intensitas yang tinggi dan interval cepat dimana memungkinkan kita untuk dapat melakukan olahraga dengan waktu yang singkat namun dengan hasil yang maksimal. Untuk Intensitas latihan interval intensitas tinggi dilakukan dengan beberapa tahapan yang dimulai dengan pemanasan statis dan dinamis. Sedangkan olahraga aerobik adalah suatu olahraga yang melibatkan pergerakan dari otot-otot besar yang dirancang utnuk meningkatkan konsumsi oksigen dan meningkatkan fungsi sistem respirasi dan sistem kardiovaskular. Kebugaran Fisik adalah dimana meningkatnya fungsi-fungsi dasar dari tubuh kita seperti sistem kardiovaskular, respirasi, pengngkatan kekuatan otot dan sebagainya. Dalam penelitian ini untuk 
pengukuran Kebugaran fisik menggunakan pengukuran Harvard Step Test. Pada tes ini individu yang diperiksa melalui uji untuk melangkah naik dan turun dari bangku (NTB) gym setingi $45 \mathrm{~cm}$ selama 5 menit pada tingkat 30 langkah/ menit. Kemudian dilakukan pemeriksaan terhadap frekuensi denyut nadi setelah test pada saat 30 detik pertama (DN1), 30 detik kedua (DN2), dan 30 detik ketiga (DN3).

Data yang dihasilkan dari sebelum perlakuan (P1) dan sesudah perlakuan (P2) diolah dan dianalisis dengan bantuan komputer menggunakan program aplikasi SPSS (Statistical Package for the Social Science) versi 23.0 Uji statistik untuk analisis data tersebut menggunakan analisis Mann-Whitney dan Wilcoxon.

\section{HASIL}

Berdasarkan Tabel 1, jumlah responden laki-laki lebih banyak dibandingkan perempuan dimana terdapat 11 orang $(68,75 \%)$ sedangkan perempuan berjumlah 5 orang $(31,25 \%)$. Sedangkan berdasarkan usia, sebagian besar responden berusia 21 tahun $(68,75 \%)$ dan tahun sebanyak 5 orang (31.25\%) berusia 20 tahun (Tabel 1). Berdasarkan hasil uji normalitas Kolmogorov-Smirnov menunjukkan distribusi data Harvard Step test (HST) sebelum dan sesudah pelatihan dengan nilai-p masing masing 0,027 dan 0,014 sehingga data berdistribusi tidak normal (Tabel 1).
Berdasarkan uji analisis Mann-Whitney yang terdapat pada Tabel 2, tidak terdapat perbedaan yang bermakna antara pelatihan Intensitas tinggi (HIIT) dan intensitas sedang sebelum $(p=0,293)$ maupun setelah pelatihan $(\mathrm{p}=0,247)$ terhadap kebugaran fisik responden penelitian. Akant tetapi, uji Wilcoxon yang membandingkan efektivitas sebelum dan setelah pelatihan pada masing-masing kelompok menunjukkan hasil yang berbeda bermakna seperti pada HIIT $(\mathrm{p}=0,001)$ dan intensitas sedang $(\mathrm{p}=0,001)$ (Tabel 3$)$.

\section{PEMBAHASAN}

Kebugaran fisik merupakan kemampuan keadaan fisik untuk dapat melakukan tugas-tugas fisik tertentu tanpa mengalami kelelahan dan masih memiliki cadangan tenaga untuk melakukan aktivitas yang bersifat mendadak. Kebugaran fisik juga dipengaruhi oleh usia, jenis kelamin, tinggi badan, berat badan, status gizi, IMT dan aktivitas fisik yang dilakukan.

Menurut Hoeger WWK dkk tahun 2009 menyebutkan bahwa kebugaran fisik adalah kemampuan untuk memenuhi tuntutan mempertahankan keselamatan hidup sehari-hari dan efektif tanpa mengalami kelelahan dan masih memiliki energi untuk melakukan aktifitas lainnya dan kegiatan rekreasi. ${ }^{8}$

Pada penelitian ini varian karakteristik sampel pada kedua kelompok tersebut menunjukkan bahwa

Tabel 1 Karakteristik Responden Penelitian

\begin{tabular}{|c|c|c|c|}
\hline Karakteristik & Jumlah $(\mathrm{N}=16)$ & Persentase (\%) & $\mathbf{P}$ \\
\hline \multicolumn{4}{|l|}{ Jenis Kelamin } \\
\hline Laki-Laki & 11 & 68,75 & \\
\hline Perempuan & 5 & 31,25 & \\
\hline \multicolumn{4}{|l|}{ Usia (Tahun) } \\
\hline 20 & 5 & 31,25 & \\
\hline 21 & 11 & 68,75 & \\
\hline \multicolumn{4}{|c|}{ Harvard Step Test (HST) } \\
\hline Sebelum Pelatihan & & & 0,027 \\
\hline Setelah Pelatihan & & & 0,014 \\
\hline Tabel 2 Uji analis & /hitney antar & r HIIT dan In & \\
\hline Variabel & Rerata \pm SB & $\mathbf{Z}$ & $\mathbf{P}$ \\
\hline \multicolumn{4}{|l|}{ Sebelum Pelatihan } \\
\hline HIIT & $60,25 \pm 15,709$ & $-1,051$ & 0,293 \\
\hline Intensitas Sedang & $54,25 \pm 18,660$ & & \\
\hline \multicolumn{4}{|l|}{ Setelah Pelatihan } \\
\hline HIIT & $74,25 \pm 13,253$ & $-1,158$ & 0,247 \\
\hline Intensitas Sedang & $66,125 \pm 16,779$ & & \\
\hline
\end{tabular}


Tabel 3 Uji Analisis Wilcoxon sebelum dan setelah pelatihan pada masing-masing kelompok

\begin{tabular}{lccc}
\hline Kelompok Pelatihan & Rerata \pm SB & Z & P \\
\hline HIIT & & & 0.001 \\
$\quad$ Sebelum Pelatihan Setelah Pelatihan & $60.25 \pm 15.709$ & -3.208 & \\
Intensitas Sedang (Moderate) & $74.25 \pm 13.253$ & & 0,001 \\
Sebelum Pelatihan & $54.25 \pm 18.660$ & -3.208 & \\
Setelah Pelatihan & $66.125 \pm 16.779$ & & \\
\hline
\end{tabular}

masing-masing subjek penelitian yang terdapat dalam kelompok 1 dan 2 memiliki karakteristik yang sama sehingga tidak akan mempengaruhi hasil penelitian. Hasil analisis analitik sebelum dan sesudah pelatihan pada kedua kelompok menunjukkan hasil analisis data yaitu ada perbedaan yang signifikan nilai Harvard step test antara sebelum dan sesudah pelatihan pada masing-masing kelompok. Pelatihan yang diberikan pada masing-masing kelompok sampel penelitian ini bertujuan untuk melihat apakah terjadi perubahan dari nilai Harvard Step Test sebelum dan sesudah pelatihan yang menunjukkan peningkatan kebugaran fisik dari subjek penelitian.

Dengan melakukan pelatihan baik itu intensitas tinggi ataupun sedang akan dapat merangsang otot-otot jantung. Dengan bertambah kuatnya otot jantung maka darah yang terpompa dari jantung akan lebih banyak sehingga suplai oksigen keseluruh tubuh akan lebih banyak pula. ${ }^{9}$ Kebutuhan oksigen didalam tubuh akibat intensitas gerakan menyebabkan tubuh mengimbangi dengan peningkatan sistem kardiovaskuler yaitu peningkatan denyut jantung, dilatasi pembuluh darah kororner, peningkatan stroke volume dan peningkatan kekuatan kontraksi jantung. Hal ini menyebabkan terjadinya peningkatan stroke volume. ${ }^{9}$

Pada subjek yang mengalami peningkatan kebugaran fisik mengalami adaptasi pada kontraksi jantung selama latihan. Peningkatan efektifitas pompa jantung sesudah diberikan beban latihan yang terus menerus dan berkesinambungan secara fisiologis maka otot jantung beradaptasi sehingga kekuatan jantung dalam memompakan darah menjadi lebih meningkat dibandingkan sebelum latihan. ${ }^{10}$ Kinerja jantung menjadi lebih baik maka dapat mencukupi suplai oksigen ke seluruh tubuh. Hal ini dapat diukur melalui pengukuran denyut nadi sesudah latihan. ${ }^{10}$ Denyut nadi sesudah sampel menjalani pelatihan menjadi lebih lambat karena telah terjadi adaptasi pada sistem kardiovaskuler terhadap latihan yang telah dilakukan dengan teratur.

Latihan interval intensitas tinggi memberikan efek fisiologis pada sistem kardiovaskuler yaitu melalui adaptasi jantung terhadap latihan interval yang diberikan. ${ }^{10}$ Pada saat melakukan latihan intensitas tinggi maka akan terjadi peningkatan sistem sistem kardiorepirasi yaitu peningkatan kebutuhan oksigen di otot yang aktif. Peningkatan kekuatan otot pernapasan (otot inspirasi dan otot ekspirasi), berkaitan erat dengan peningkatan metabolisme energi di dalam mitokondria sel otot pernapasan yang aktif. Sel otot yang berkontraksi membutuhkan banyak ATP. Akibatnya otot yang dipakai dalam latihan intensitas tinggi membutuhkan lebih banyak oksigen (O2) dan menghasilkan karbondioksida $(\mathrm{CO} 2)^{10,11}$

Peningkatan kardiovaskuler juga terjadi dikarenakan terjadinya peningkatan denyut jangtung saat latihan. Peningkatan denyut jantung saat latihan ini akan meningkatkan stroke volume. ${ }^{11}$ Peningkatan stroke volume dan peningkatan frekuensi jantung dapat menyebabkan peningkatan cardiac output yaitu volume darah yang dikeluarkan oleh kedua ventrikel per menit. ${ }^{11}$ Peningkatan ini disertai dengan vasodilatasi pembuluh darah untuk membawa oksigen ke otot yang aktif.

Pelatihan intensitas tinggi menyebabkan peningkatan stroke volume sehingga terjadi penurunan denyut nadi sementara cardiac output tetap. Hal ini menyebabkan efisiensi otot jantung dalam menyuplai darah ke seluruh tubuh. Efisiensi denyut jantung ditunjukkan dengan penurunan denyut nadi.

Uji beda pelatihan yang dinilai dengan uji Mann-whitney menunjukkan tidak ada hubungan antara pelatihan olahraga aerobik intensitas tinggi (HIIT) dan olahraga aerobik intensitas sedang. Banyak faktor yang mempengaruhi hasil dari uji analisis tersebut seperti subjek yang kurang memahami program yang sudah diberikan, subjek tidak melakukan program sebagaimana mestinya dan subjek tidak berlatih tepat waktu dari yang dijadwalkan.

Sekalipun melalui analisis Mann-whitney menunjukkan bahwa data dari kedua jenis pelatihan menghasilkan angka yang tidak bermakna, tapi dapat kita lihat dari hasil analisis deskriptif bahwa terdapat perbedaan nilai rerata sesudah pelatihan dari kedua kelompok yang menunjukkan terdapat perbedaan bermakna setelah menjalani Harvard 
Step Test (HST). Pada kelompok satu yang diberikan pelatihan olahraga aerobik intensitas tinggi (HIIT) nilai rerata HST 60,25 sebelum pelatihan dan 74,25 setelah pelatihan. Sedangkan pada kelompok 2 yang diberikan pelatihan olahraga aerobik intensitas sedang nilai rerata HST 54,25 sebelum pelatihan dan 66,12 setelah pelatihan. Terjadi perbedaan peningkatan antara pelatihan olahraga aerobik intensitas tinggi (HIIT) sebanyak 14 poin dan pada olahraga aerobik intensitas sedang sebanyak 11 poin. Hal ini menunjukkan bahwa kelompok yang diberi pelatihan olahraga aerobik intensitas tinggi mengalami peningkatan kebugaran fisik dari pada kelompok yang mendapat pelatihan olahraga aerobik intensitas sedang.

Perbedaan ini terjadi karena pada latihan olahraga aerobik intensitas tinggi (HIIT) subjek melakukan gerakan dengan intensitas tinggi dan diselingi gerakan dengan intensitas yang rendah. Sedangkan pada olahraga aerobik intensitas sedang subjek hanya melakukan berlari konstan tanpa adanya perubahan tempo seperti pada aerobik intensitas tinggi (HIIT). Latihan intensitas rendah yang diselingi diantara latihan intensitas tinggi pada latihan interval membantu pembuangan metabolisme dari otot selama periode istirahat pada saat latihan interval intensitas tinggi (HIIT) sedang dilakukan oleh tubuh. ${ }^{10}$ Perubahan periode latihan yang dilakukan bergantian ini membantu tubuh meningkatkan volume dalam mengkonsumsi oksigen selama latihan. Hal ini dikarenakan sel paling sedikit mengkonsumsi oksigen adalah pada saat otot dalam keadaan istrahat. Latihan ini juga meningkatkan adaptasi sistem kardiovaskuler terhadap latihan interval yang dilakukan.

Dari hasil tersebut dapat kita lihat bahwa pada pelatihan intensitas tinggi (HIIT) semua subjek yang melakukan pelatihan mengalami peningkatan dari nilai HST dan sudah tidak ada lagi subjek yang termasuk dalam kriteria kurang. Peningkatan juga terjadi pada subjek kelompok pelatihan aerobik intensitas sedang tetapi peningkatan yang terjadi pada beberapa subjek masih tetap termasuk dalam kriteria Kurang. Hanya 1 orang yang sebelumnya dengan kriteria kurang mengalami peningkatan menjadi kriteria sedang. Dimana hal ini menunjukkan bahwa pelatihan dengan olahraga aerobik intensitas tinggi (HIIT) sedikit lebih efektif dari pada melakukan olahraga aerobik intensitas sedang. Hal ini juga sesuai dengan penelitian sebelumnya tentang pengaruh senam aerobik low impact dan high impact terhadap kebugaran fisik terhadap 20 orang didapatkan hasil yang bermakna terhadap latihan senam aerobik low impact dan high impact terhadap hasil kesegaran jasmani terutama pada obesitas. ${ }^{12}$ Berdasarkan penelitian tersebut didapatkan hasil bahwa latihan senam aerobik high impact memberikan hasil yang lebih baik dibandingkan low impact terhadap hasil kebugaran fisik.

\section{SIMPULAN}

Olahraga aerobik intensitas sedang ternyata berpengaruh terhadap peningkatan kebugaran fisik. High Intensity Interval Training (HIIT) ternyata berpengaruh terhadap peningkatan kenugaran fisik. Tidak terdapat perbedaan yang signifikan diantara olahraga aerobik intensitas sedang dan High Intensity Interval Training (HIIT).

\section{KONFLIK KEPENTINGAN}

Tidak terdapat konflik kepentingan dalam penulisan laporan penelitian.

\section{ETIKA PENELITIAN}

Komisi Etik, Fakultas Kedokteran, Universitas Udayana, Bali, Indonesia telah memberikan persetujuan etik sebelum penelitian berjalan.

\section{PENDANAAN}

Penulis membiayai penelitian ini secara mandiri tanpa melibatkan pihak sponsor, beasiswa, atau sumber pendanaan lainnya.

\section{KONTRIBUSI PENULIS}

Seluruh penulis berkontribusi dalam penulisan penelitian ini baik dari tahap penyusunan kerangka penelitian, pencarian data, analisis data, hingga interpretasi data penelitian yang dibuat dalam narasi laporan penelitian.

\section{DAFTAR PUSTAKA}

1. Ruegsegger GN, Booth FW. Health Benefits of Exercise. Cold Spring Harb Perspect Med. 2018;8(7):a029694.

2. Patel H, Alkhawam H, Madanieh R, Shah N, Kosmas CE, Vittorio TJ. Aerobic vs anaerobic exercise training effects on the cardiovascular system. World J Cardiol. 2017;9(2):134-138.

3. Bloomer RJ, Goldfarb AH. Anaerobic exercise and oxidative stress: a review. Can J Appl Physiol. 2004;29(3):245-263.

4. Suter E, Marti B, Gutzwiller F. Jogging or walking--comparison of health effects. Ann Epidemiol. 1994;4(5):375-381.

5. Tremblay MS, Colley RC, Saunders TJ, Healy GN, Owen N. Physiological and health implications of a sedentary lifestyle. Appl Physiol Nutr Metab. 2010;35(6):725-740.

6. Nokes N. Relationship between physical activity and aerobic fitness. J Sports Med Phys Fitness. 2009;49(2):136-141.

7. Laursen PB, Jenkins DG. The scientific basis for high-intensity interval training: optimising training programmes and maximising performance in highly trained endurance athletes. Sports Med. 2002;32(1):53-73.

8. Hoeger WWK, Hoeger SA, Hoeger CI, Fawson AL. Lifetime Physical Fitness and Wellness: A Personalized Program. $10^{\text {th }}$ Edition. Paper Back Cengage Learning: Belmont, USA. 2009, p. 1-516 
9. Montoye HJ, Willis PW 3rd, Cunningham DA, Keller JB. Heart rate response to a modified Harvard step test: males and females, age 10-69. Res Q. 1969;40(1):153-162.

10. Hannan AL, Hing W, Simas V, et al. High-intensity interval training versus moderate-intensity continuous training within cardiac rehabilitation: a systematic review and meta-analysis. Open Access J Sports Med. 2018;9:1-17.

11. Lee BA, Oh DJ. The effects of long-term aerobic exercise on cardiac structure, stroke volume of the left ventricle, and cardiac output. J Exerc Rehabil. 2016;12(1):37-41.
12. Said M, Lamya N, Olfa N, Hamda M. Effects of high-impact aerobics vs. low-impact aerobics and strength training in overweight and obese women. J Sports Med Phys Fitness. 2017;57(3):278-288

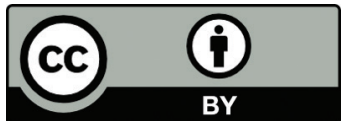

This work is licensed under a Creative Commons Attribution 